\title{
Management Model Implementation Strategy Universal Service Obligation (USO) Indonesia
}

\author{
Ihwana As'ad', Muh. Nur Fithri Dahlan' \\ \{ihwana_ana@yahoo.com ${ }^{1}$, muhnurfithri@gmail.com ${ }^{2}$ \} \\ 1,2 STAI YAPIS Takalar, JL. H. Abd Majid Pali, Kacci - Kacci, \\ Kelurahan Sombala Bella, Sulawesi Selatan, Indonesia
}

\begin{abstract}
USO is a part of the main plan of Information and Communication Technologies (ICT) in a country, monitored by ITU and will be indexed every five years. In 2009 the Indonesian ICT index was far below that of Malaysia. Therefore, the purpose of this paper is to find out the implementation of ICT especially the implementation of USO in Indonesia. This paper is expected to be a guideline for planning and implementation in Indonesia. In particular, the objective is to find out the factors that influence the implementation of USO in Indonesia. Data collection was carried out based on the strategy management framework [1]. This model framework is a comprehensive strategy management model through 4 (four) stages, namely, 1) environmental observation, 2) strategy planning, 3) implementation of the strategy, and 4) assessment and control. In accordance with the objectives and objectives of this study, the method of data collection conducted is qualitatively through content analysis using atlas.ti. Data comes from documents implementing USO in Indonesia. The results of the study found that the factors that influenced the implementation of USO in Indonesia were management strategies, namely natural environment, strategic planning, strategy implementation and monitoring and evaluation.
\end{abstract}

Keywords: USO, and Management strategies.

\section{Introduction}

The term of Universal Service Obligation (USO) means Universal Service Obligation, a term that refers to the national plan of a country under the supervision of the International Telecommunication Union (ITU) to ensure that each ITU member country is obliged to plan and implement a strategy to overcome the digital divide between urban communities and rural communities [2].

USO in the telecommunications sector is the cooperation of countries around the world who join the world telecommunications organization ITU, especially in ITU-D (Development) as a collaborative partnership with several countries (World Summit On Information Society Declaration) in the 2003 Tokyo Declaration, Geneva Declaration 2003, and Tunis Declaration 2005 [3].

With the rapid development of communication technology, the strategies and implementation of Universal Services and Universal Access appear to occur simultaneously in developing countries. In the beginning, developing countries focused on Universal Access, but because the use of mobile phones was increasingly affordable by the public, and the provision of a wider range of services, developing countries also planned and implemented Universal Services. This development has brought changes and focused services targeted from urban 
areas to rural areas. In addition, the implementation of universal services not only focuses on mobile phone technology but begins to take into account internet services. Therefore, the use of the term Universal Service is more accurate [4].

USO is part of the Master Plan for Information and Communication Technology (TMK) in a country, and is recognized as a vital pillar of modern society, and various sectors depend on TMK, such as administration, education, health, business, finance and tourism [2].

ITU as an international organization that assesses the growth of TMK in Asian-African countries, assesses every five years using valuation methods called the TMK index, namely: 1) TMK infrastructure, 2) Facilities for individuals and homes get and use TMK, 3) Use of TMK for companies, and 4) TMK sector and TMK goods business. The results of the ITU assessment for member countries provide information about the impact and development of ICT infrastructure in a country. In addition to assessing it every five years, ITU and member countries carry out activities to discuss the obstacles faced by member countries in implementing USO.

Various studies on the development of USO implementation have been carried out. Some studies that are closely related to Indonesia are as follows: [5],[6],[7],[8],[9] and [10].

From the results of the above research, discuss USO's strategies, policies, finance, procedures and programs. The findings of this study are summarized in the strategy management component, and no previous research has discussed management strategies in USO implementation.

Management strategies are useful to assist organizations in designing better strategies by using the right approach in determining systematic, logical and rational strategy choices [11]. Sets out three components of the basic strategy - goals or targets, ways of acting, and allocation of resources [12]. Focuses on five components, namely marketing of production, marketing and product combination, competition, synergy, and the decision to sell or buy [12],[13]. Focuses on three factors, namely decision making, effective strategy formulation and achievement of company goals [14], and focus on four factors, namely environmental observations (internal and external), strategy formulation (vision, strategy, policies), implementation strategies (programs, finance, procedures), escort and evaluation [1].

The beginning of the implementation of management strategies was carried out in the military world. Currently it is growing rapidly in various fields of organization, whether business organizations, non-business organizations (public sector) or in family units. Strategic management is a guide for organizations for a better future. This guide is a strategy to achieve the organization's vision. The organization will identify the strategy by adjusting the position of the organization with strengths and strengths and opportunities in the environment to achieve the determined vision.

The implementation of management strategies in business organizations and non-business organizations has similarities and differences according to the characteristics of each organization [15]. The difference lies in the value and purpose. Business organization value setting is a philosophy that contains free competition between organizations, through the use of all available resources to achieve goals. This is used to maintain and develop strategic management in the long term through sustainable profitability in competition. On the other hand, the philosophy of nonbusiness organizations is based on service and humanity aimed at achieving public welfare.

Strategic management is an important component of successful institutional or business management [16]. Similarly, the success of USO implementation is based on the strategies carried out by each country. The strategy is about forming, forming processes and how to implement designs [17]. 
USO is a special activity designed by ITU to reduce telecommunication inequalities to all communities both in urban and rural areas. ITU is a world organization in the field of telecommunications, which has membership in almost every country in Asia and Africa. Countries in Asia and Africa have large areas and most of them live in rural areas. With such a situation, strategies and programs are needed so that communication tools can be utilized properly by the community both those who live in urban areas and rural areas.

Telecommunications has a very important role in all aspects of human life today. Through this universal service program, it is expected that all levels of society can utilize telecommunications facilities. ITU as a world institution recommended several declarations between them, the Tokyo Declaration in 2000 which stated that the entire Asia Pacific region must obtain access to information for all levels of society. The Summit on Information Society (WSIS) in Geneva in December 2003 stated that in 2015 the entire world would be able to reach telecommunications networks for the education, health and government sectors [5]. And the last declaration in Tunisia in 2005. The purpose of this declaration is so that telecommunications infrastructure development can be realized to support the provision of good telecommunications services, internet telephone services in all urban areas and in rural areas, especially rural areas that are not economically profitable.

\section{Method}

As mentioned earlier above, this research is a study of the implementation of the USO strategy in Indonesia, strategy model [1]. USO in Indonesia is carried out by the government, the Ministry of Communication and Information, and is technically run by the Information and Finance and Management Providing Agency (BP3TI).

The method used in this study is a qualitative method using content analysis and interview techniques to policy makers at the Ministry of Communication and Information, especially at the BP3TI office.

\section{Findings}

Based on the purpose of the study is to find out the factors that influence the implementation of USO in Indonesia, using the management strategy model as the basic model [1]. Overall, the results of this study found that all the factors and components found in the initial model of this study were clearly found in the implementation of USO in Indonesia.

After analyzing the results of qualitative data collection, the researcher found that four strategic management factors exist in the implementation of USO in Indonesia. The four factors are: 1) surrounding environment, 2) strategy planning, 3) implementation of strategy and 4) supervision and evaluation.

After studying these four factors and considering the diversity of research and the fact that the four factors are related to each other, the researchers found that all of these factors could be designed to make a better model for the implementation of USO in Indonesia.

Through extensive literature review, according to the preliminary theory it was found that the factors and components that determine the success of an institution are in accordance with the four strategic management processes. The four strategies are well implemented and systematic.

After examining all research data and taking into account any similarities and differences, then find a strategy strategy management model for USO. The researcher find that the management model of the USO implementation strategy is very important to follow each steps in accordance with the processes that exist in the management factor [1]. All activities will 
succeed if all the processes and steps are followed carefully, correctly, systematically, and focused.

\section{References}

[1] Wheelen, T. L., \& Hunger, J. D. Startegic Management and Bussiness Policy (Tenth Edit.). New Jesley: Pearson Prentice Hall, 2006.

[2] InfoDev/ITU. Module 4 . Universal Access and Service. ITU, 2009. Retrieved from www.ictregulationtoolkit.org/en/section.3126.html

[3] Balai Penyedia dan Pengelola Pembiayaan Telekomunikasi dan Informatika (BP3TI) Direktorat Telekomunikasi Khusus, P. dan K. P. U., 2011.

[4] Oestman, S., \& Dymond, A. Universal Access and Service, 2008. Retrieved from www.ictregulationtoolkit.org/en/Document.3606.pdf?

[5] Gunawan, V. A. Evaluasi Pelaksanaan Universal Service Obligation (USO) Tahun 2004 Di Provinsi Jawa Tengah, 2006.

[6] Nurwijayanti. Prioritasi Implementasi USO (Universal Service Obligation) Telekomunikasi di Daerah Rural, 2003.

[7] Pane, T. A. Implementasi Universal Service Obligation dengan Pemanfaatan Frekuensi $2.4 \mathrm{GHz}, 2006$.

[8] Prianova, I. P. Strategi Implementasi Penyediaan Pusat Layanan Internet Kecamatan (PLIK) Pada Pelaksanaan Kewajiban Pelayanan Universal Telekomunikasi (KPU/USO) di Indonesia. Universitas Indonesia, 2010.

[9] PUSTRAL-UGM. TECHNOLOGY ASSESSMENT FOR UNIVERSAL SERVICE OBLIGATION PRACTICES, 2007.

[10] Ramos, B. The Impact of Universal Service Oobligations and Other External and Cross Subsidies on Teledensity in Developing, 2006.

[11] David, F. R. Strategic Management (Global Edi.). Boston, 2013.

[12] Chandler, A. D. Strategy and Structure: Chapter in the History of the Industrial Enterprise. Cambridge: The M.I.T Press, 1962.

[13] Ansoff, H. I. Corporate Strategy. London: Penguin, 1965.

[14] Glueck, W. F. Business Policy and Strategic Management. Tokyo: Mc Graw-Hill International Book Company, 1980.

[15] Nawawi, H. Manajemen Strategik Organisasi Non Profit Bidang Pemerintahan dengan Ilustrasi di Bidang Pendidikan. Yogyakarta: Gadjah Mada University Press, 2003.

[16] Bowman, C. Strategy in Practice. London: Prentice Hall Europe, 1998.

[17] Norton, B., \& Irving, R. Strategy in a Week. Oxon: Hodder Arnold, 2002. 